\section{Kunsten at skrive en føljetonroman}

Afforfatter, lektor Torsten Svensson

\section{Petrograd...!}

Anna Aleksandrovna stod ved et af de hoje vinduer i sit sovevarelse og kiggede adspredt ud over byen.

Hun rynkede let på nasen, mens hun nasten uhorligt mumlede navnet for sig selv. Hun syntes stadig, det lod forkert - selvom det efterhainden var tre är siden, hovedstaden $i$ zarriget kom til at hedde sadan...

En lok af Annas rodgyldne hair havde losnet sig fra den sirlige frisure, det var sat $i$. Hun strog den vak fra kinden, mens hun lod blikket vandre videre.

Vintervejret viste sig fra sin smukkeste side denne februardag i 1917. Formiddagssolen kastede sit klare lys ned over den isdakkede Fontanka kanal foran palaet, hvor hun boede. Strålerne kastede lange skygger hen over de pastelfarvede husfacader ovre på den modsatte bred - og oppe over tagryggene rejste Isaak katedralens kuppel sig som en stor, gylden halvkugle.

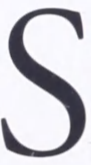
ådan begynder Grevinde Ismajlova. Det er en føljetonroman. En af den slags, man finder i ugebladene. Hjemmet, Familie Journalen og alle de andre.

Denne roman har man kunnet læse for nylig i Hjemmet. Gennem de sidste seks syv år har jeg skrevet en række romaner til dette blad, og Grevinde Ismajlova er den senest publicerede af dem.

Mange forestiller sig, at sådan nogle historier altid udgives under pseudonym. Men jeg har altid brugt mit eget navn, og det er der ikke noget usædvanligt i.

$\mathrm{E}$ $\mathrm{n}$ føljeton har selvfølgelig en del til fælles med en roman, der udgives $i$ bogform. Men på en række punkter adskiller den sig markant fra bogen. Det må den nødvendigvis gøre, for læsesituationen er helt anderledes. Et kapitel i en føljeton er kun på godt 3000 ord, og det tager vel et sted mellem ti og tyve minutter at læse det. På denne korte tid skal læseren nå at blive fanget af handlingen. Få lyst til at læse fortsættelsen, som kommer en uge efter.

Hvis det skal lykkes, er det ikke ligegyldigt, hvordan historien fortælles. Det vil jeg forsøge at vise med nogle eksempler fra Grevinde Ismajlova. Ikke fordi denne roman er en bedre eller mere typisk repræsentant for genren end så mange andre men simpelthen fordi, det er mest nærliggende for mig at tage udgangspunkt i den.

Jeg har i sagens natur læst mange føljetonromaner. Og som nævnt har jeg også skrevet en del af slagsen. Undervejs har jeg ikke kunnet undgå at gøre mig en række erfaringer. For redaktionen på bladet ved ganske nøje, hvad de vil have, og hvad de ikke kan bruge.

Det er nogle af disse erfaringer, der viderebringes her. Jeg tror, at de øvrige forfattere, som skriver til Hjemmet, vil kunne nikke bifaldende til det meste - selvom vi selvfølgelig hver især har vores egen stil. På de andre ugeblade er der måske nogle ting, man ville vægte lidt anderledes. Men jeg bilder mig ind, at mine betragtninger i det store og hele er dækkende for genren.

\section{Læserne}

Ten føljetonroman er det forholdsvis klart, hvem man skriver til. Sådan er det ikke nødvendigvis med en bog. Den sendes på markedet og finder sin læserskare - 
uden at forfatteren og forlaget på forhånd behøver at vide, hvem det er. En roman i et ugeblad har derimod en nogenlunde fast defineret kreds af læsere, og det er naturligvis dem, historien henvender sig til.

Hjemmet har et oplag på knap 220.000 eksemplarer, men ifølge en række markedsundersøgelser når bladet ud til omkring tre gange så mange mennesker. Grevinde Ismajlova er også udkommet i Hjemmets søsterblade i Sverige og Norge. Deres oplagstal er tilsammen på over en halv million eksemplarer, og også her sættes antallet af læsere til at være tre gange så højt. De har selvfølgelig ikke læst denne roman alle sammen. Man regner med, at omkring 30 procent af bladenes faste læsere følger med i føljetonerne. Men der er stadig tale om en ganske stor - og derfor også meget bred - læserskare.

Det må man selvfølgelig tage hensyn til. For bare at tage et enkelt eksempel, må man i forbindelse med Grevinde Ismajlova gå ud fra, at en del af læserne ikke kender til russernes brug af fadernavne - og at de derfor kan blive forvirrede over, at en person både omtales som Doktor Petrov og Sergej Mikhailovitch. Det ville imidlertid ødelægge lidt af den russiske tone, hvis man helt undlod brugen af fadernavne. Så derfor endte det med en mellemløsning, hvor de bruges indimellem.

Undersøgelserne viser, at der er langt flere kvinder end mænd, der læser ugebladene. De fleste befinder sig i den modne og den lidt ældre aldersgruppe. Og hvis man meget kort skal beskrive deres livsholdning, så er det de bløde, menneske-

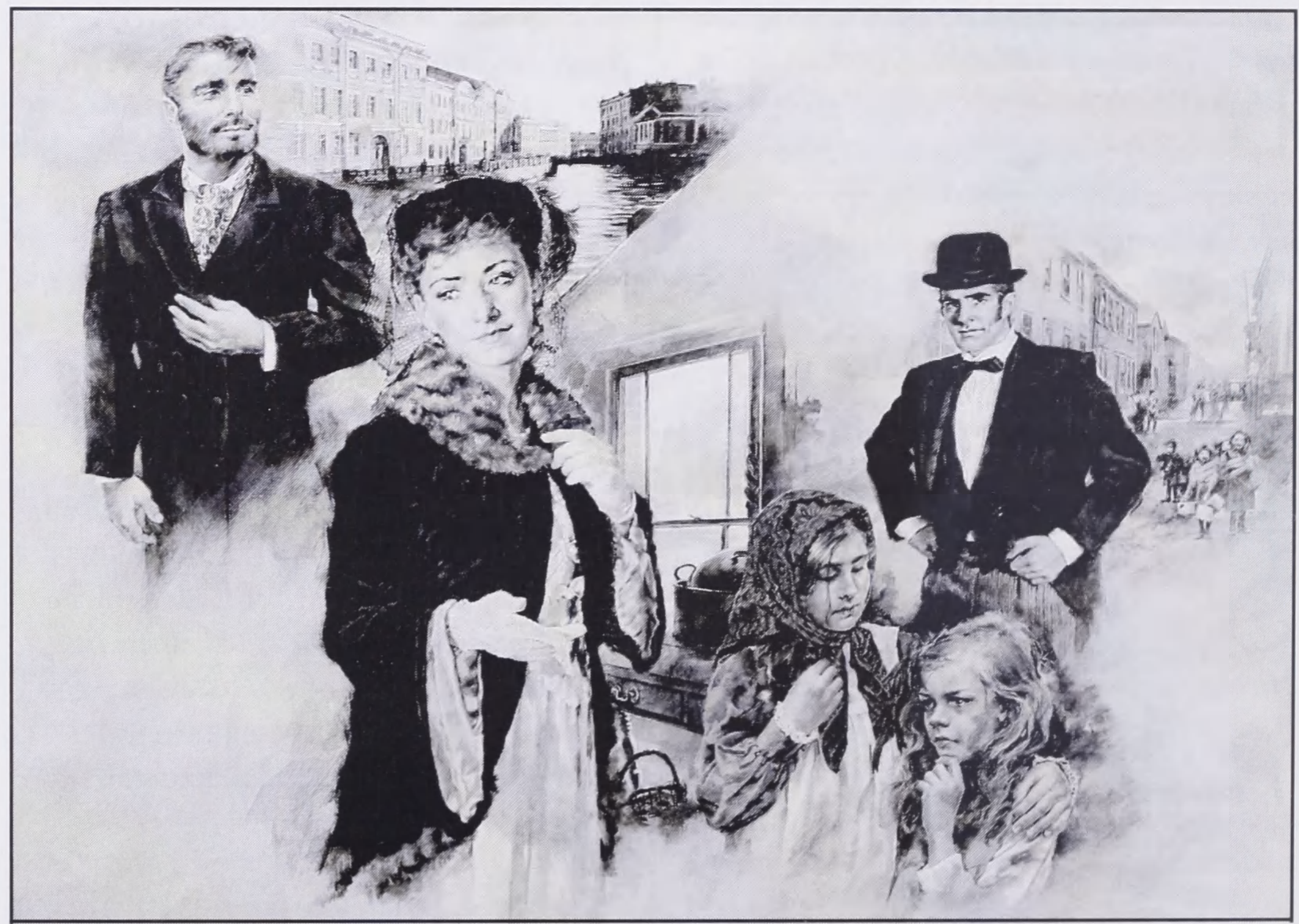

Illustrationerne til "Grevinde Ismajlova" er udfort af den engelske tegner Lesley Mackenzie. De gengives her med hendes venlige tilladelse. Til forste kapitel i en foljeton er illustrationen almindeligvis en collage. Man ser romanens hovedpersoner, og ofte fär man også en antydning af de vasentligste konflikter i historien. 
lige værdier, der tæller mest.

Det er blandt andet derfor, at en føljetonroman betoner det følelsesmæssige så højt. Uanset hvor megen dramatik den indeholder, er det altid den menneskelige historie, som er kernen i handlingen.

\section{Fortællestilen}

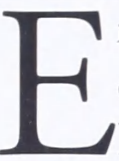
$\mathrm{n}$ føljetonroman fortælles generelt $\mathrm{i}$ en række klart afgrænsede scener. Og læserne skal hele tiden kunne se dem lyslevende for sig.

Derfor får den alvidende forfatter næsten aldrig lov til at komme til orde. Det ville ødelægge fornemmelsen af at være tæt på det, der foregår. Det, som kommer med i teksten, er i almindelighed kun det, som personerne i romanen ser og hører - eller eventuelt tænker sig til. Der er ingen analyser og uddybende forklaringer af det, der sker. Derimod er der mange beskrivelser af landskaber, bygninger og interiører, så læseren hele tiden får nogle klare billeder på nethinden. Disse beskrivelser må dog ikke være for lange, for så går handlingen i stå.

I starten af Grevinde Ismajlova er det vigtigt, at læseren med det samme får et klart indtryk af Anna og hendes personlighed. Hun lever i overflod. Er vant til at fă, hvad hun peger på, af sin mand. Men der er noget tomt og indholdsløst over hendes tilværelse. Hendes rolle i ægteskabet består mest i at være til pynt - men hun har dog endnu ingen tanker om, at det kunne være anderledes. Tid har hun masser af, og faktisk keder hun sig lidt.

Sådan som det står her, kan man imidlertid ikke skrive det i en føljeton. Det er jo netop et eksempel på fortællestilen med den alvidende forfatter.
I stedet må der tegnes nogle billeder af Anna, der bringer læseren ind på livet af hende.

Hun vendte sig fra vinduet og gik hen til et toiletbord af blankpoleret rosentra. Her satte hun sig og betragtede sit ansigt $i$ det ovale spejl over bordpladen.

Selvom hun havde passeret de tredive år, virkede huden lige så glat og fin, som den altid havde gjort. Og der var stadig ingen rynker at se omkring de mandelformede, gronne ojne.

Rutineret kom hun en smule morkt pudder pà kinderne for at fä dem til at synes mindre runde. Og lidt på siden af nasen, så den ikke virkede for bred.

Med en bekymret mine rakte hun ud efter en flakon. Det var hendes yndlingsparfume. Men den var efterhänden kun kvart fuld; og forretningen, der solgte den, vidste ikke, hvornår de kunne levere den igen. Det var på grund afkrigen, sagde de. Der var problemer med at fä varer frem.

Hun sukkede svagt. Satte flakonen tilbage og tog en ved siden af. Et andet fransk marke, som stadig kunne skaffes...

I den næste scene møder Anna tilfældigt lægen Sergej Mikhailovitch. Han fortæller hende om de kummerlige forhold, som størstedelen af byens befolkning lever under. Og da hun vægrer sig ved at tro ham, tilbyder han at tage hende med på en køretur til Narva kvarteret. Efter et øjebliks tøven tager Anna imod denne udfordring - og hun er helt uforberedt på det syn, der møder hende i den efterfølgende scene:

Kvinder i uformeligt, slidt toj med store, uldne torklader viklet om skuldrene. Tynde, pjaltet kladte born. Mand i slidte, 
stovede jakker...

$$
\text { Langere fremme havde nogle }
$$

kvinder samlet sig foran trappen til en bagerbutik. Og i lobet afkort tid kom adskillige andre til og stillede sig op $i$ køen.

En spinkel, ung pige med et laset, rodternet torklade kom lobende. "Har de fäet brod?" spurgte hun stakaindet og stirrede forhåbningsfuldt op mod forretningen.

I det samme kom bageren frem $i$

doren til sin butik. "Desvarre...!" sagde han og rystede på hovedet.

Den unge pige lod skuffet skuldrene synke. Stod lidt og så opgivende frem for sig. Og for hun vendte omkring og traskede bort, nåede Anna at se, hvordan en enlig tare banede sig vejned over hendes kind.

Tause og forknytte begyndte de ovrige også at gå hver til sit. Et lille barn, der sad pà sin mors arm, begyndte at grede. En gammel kone foldede handerne og bad en stille bon.

\section{Vægtning af handlingselementerne

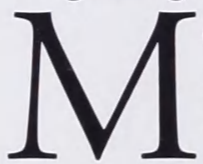 ed de scener, som er citeret ovenfor, er den første af handlingsgangene i denne} føljetonromanen i spil. Det er den, man kunne kalde den personlige udviklingshistorie. Efter at have oplevet sulten og nøden blandt byens fattige er Anna ikke længere den samme som før, og hun prøver på sin egen lidt famlende måde at gøre noget for at hjælpe nogle af disse mennesker. Det giver hende en masse problemer - bl.a. i forholdet til hendes mand, der er godsejer og en ledende embedsmand i zarens ministerium - men det gør hende også til en stærkere og langt mere selvstændig person.

Der er sikkert nogen, som vil mene, at dette tema er en smule letkøbt. Annas handlinger kunne måske nok give anledning til en del undren og hævede øjenbryn hos den russiske adel i 1917. Men for os i dag er det næppe særlig provokerende. Tværtimod: Det, Anna foretager sig, er jo ikke andet, end hvad læseren selv ville have gjort, hvis hun havde været i hendes sted - og i øvrigt havde det fornødne mod.

Hvorfor ikke skrive noget mere udfordrende - noget der kunne rokke ved vores vanetænkning? Hvad med f.eks. at lade Anna gå til yderligheder? Hun kunne måske involvere sig med nogen, som brugte vold og politiske drab i kampen for bedre leveforhold. Så kunne vi se, hvor langt hen ad vejen vi kunne bifalde hendes handlinger. Prøve vore egne grænser af. Drage paralleller til nutiden med sult og fattigdom i den tredje verden.

Det kunne der givetvis komme en spændende, skønlitterær bog ud af. For i sådan en kan læseren have et distanceret, intellektuelt forhold til hovedpersonen. Men i en føljetonroman ville det aldrig gå! I Grevinde Ismajlova er det afgørende, at læseren kan identificere sig med Anna. At hun kan bifalde - eller i hvert fald forstå hendes handlinger. Ellers ville hun ikke engagere sig så meget $\mathrm{i}$ historien, at hun fulgte den uge efter uge.

Nogle scener efter er der en ny handlingstråd, som vikles ind i romanen.

Et par dage efter sad Sergej ved sit skrivebord og bladede i nogle journaler. Men han havde svart ved at samle tankerne om sit arbejde. Og indimellem lagde han papirerne fra sig. Lanede sig tilbage i stolen og sa drommende udi luften.

Hvorfor kunne han ikke glemme hende? Grevinden, som havde varet med ham nede i Narva kvarteret forleden dag..

Han kunne stadig se hende for sig, som hun sad $i$ hans vogn efter besoget dernede. 


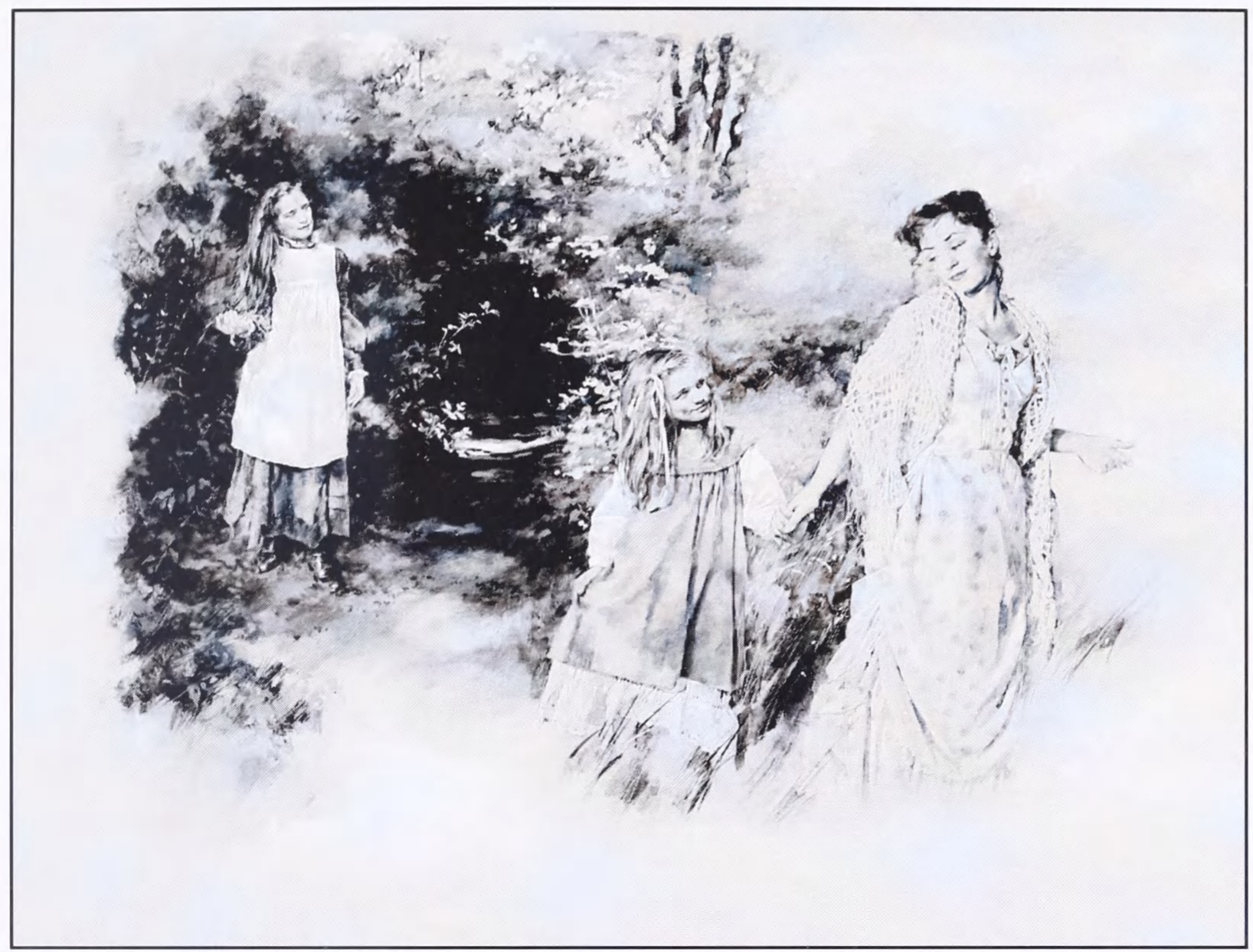

Der ligger adskillige overvejelser bag valget af illustration til de enkelte kapitler. Her har man brugt en spadseretur ved godset Lipovskoje. En lille, idyllisk episode, der på denne måde fär sarlig vagt som modstykke til de mange dramatiske begivenheder, som handlingen også byder på.

Hendes laber sitrede... som om hun havde svart ved at holde graden tilbage; og fortvivlelsen nermest lyste ud af de konne, gronne ojne.

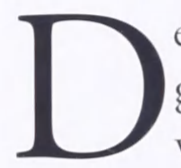
et er ikke kun Sergej, som ikke kan glemme Anna. Hun har også vanskeligt ved at få ham ud af tankerne. Og dermed er der lagt op til en kærlighedshistorie. I dette tilfælde der tale om et klassisk trekantsdrama, hvor Anna er splittet mellem Sergej og sin mand.

Kærlighed spiller næsten altid en fremtrædende rolle i en føljeton. Og det gør den også i denne roman. Derfor er det vigtigt, at læseren lever sig ind i kærlighedshistorien. Danner sig en mening om den.
Skal Anna blive hos sin mand, eller skal hun give efter for Sergejs tilnærmelser?

Hvis grev Ismajlov var beskrevet mere eller mindre usympatisk, ville der ikke være megen brod i den konflikt, Anna befandt sig i. Så ville læserens holdning være givet på forhånd: Se dog at komme ud af det ægteskab i en fart og kast dig i armene på Sergej så hurtigt, du kan!

Men greven er både galant og opmærksom. Og bortset fra, at der ikke er børn i ægteskabet - hvilket er en stor sorg for Anna - har de det egentlig udmærket sammen. Så det er ikke let at give Anna et råd, og det skal det heller ikke være.

I løbet af romanen bliver det dog mere og mere klart, at Anna og hendes mand 
er ved at glide fra hinanden. Men det er ikke kun, fordi Anna er fascineret er Sergej. Det er nok så meget, fordi de to ægtefællers verdensopfattelse begynder at blive for forskellig.

Dermed er de to første handlingselementer - udviklingshistorien og kærlighedshistorien - snoet så grundigt ind i hinanden, at det af og til kan være svært at se, hvilken af dem der er i fokus i øjeblikket.

Sådan er det i historien her. Og sådan er det jo også i de fleste andre romaner, hvor kærlighed spiller en fremtrædende rolle. Hvis kærlighedshistorien skulle stå alene, ville den hurtigt komme til at virke en smule uinteressant. Udviklingshistorien i denne roman kunne derimod godt klare sig, selvom der ikke var kærlighed med i spillet.
Men den ville ikke blive nær så farverig og lidenskabelig.

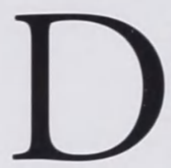
et tredje og sidste handlingselement i Grevinde Ismajlova er den dramatiske, politiske historie: Den folkelige opstand i februar. Zarens afgang og dannelsen af en delvis demokratisk regering. Bolsjevikkernes magtovertagelse i oktober. Undertrykkelsen af anderledes tænkende...

Den alvidende forfatter - som kunne fortælle længe og indgående om disse historiske begivenheder - er som nævnt sat fra bestillingen i denne genre. Så det, vi hører til dem, er fortrinsvis det, som Anna selv er vidne til.

Her opdager hun eksempelvis, at der er posteret militær på Litejnij boulevar-

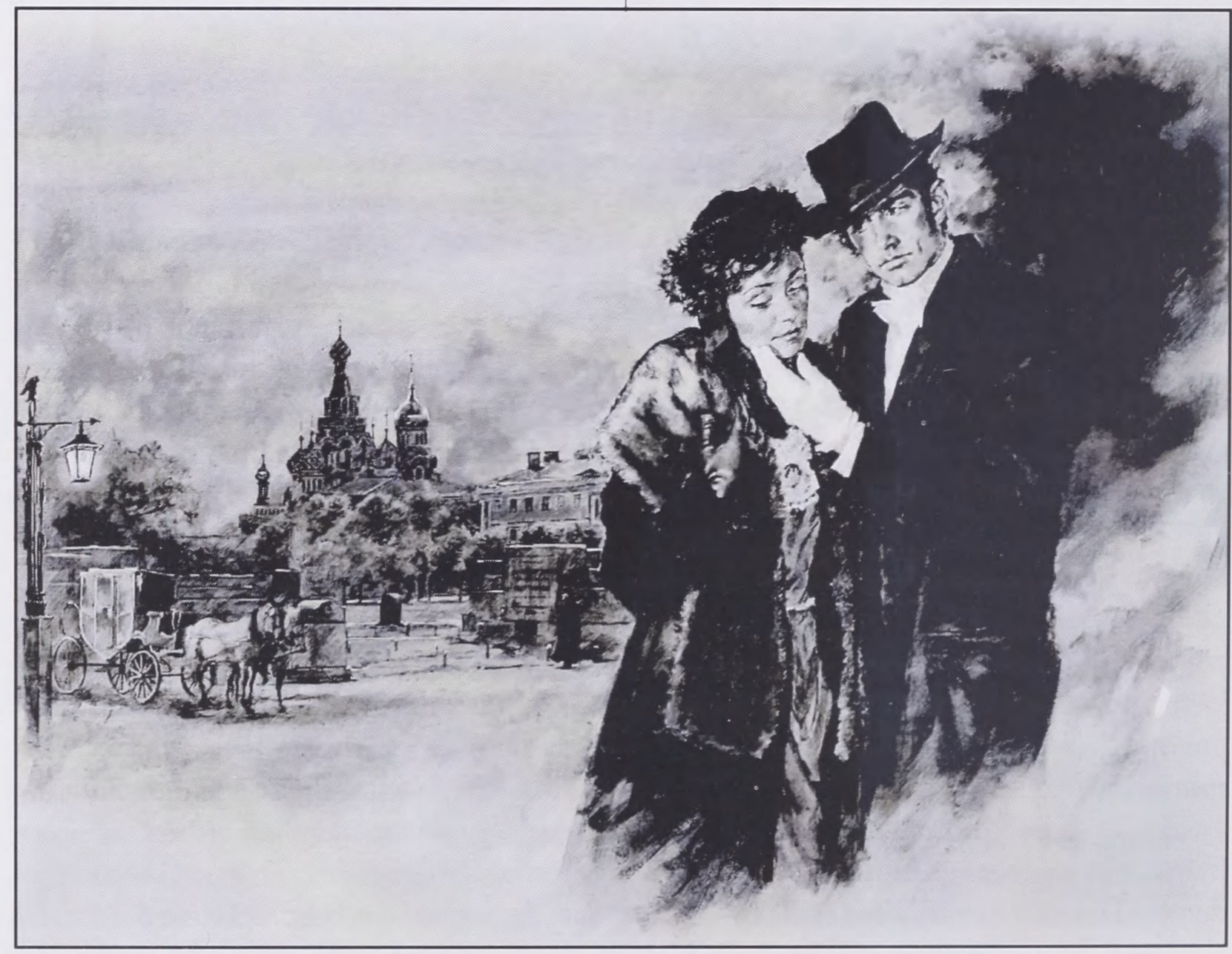

Her er det karlighedshistorien, der er i fokus - og de truende skyer over Petrograd er trangt $i$ baggrunden. 


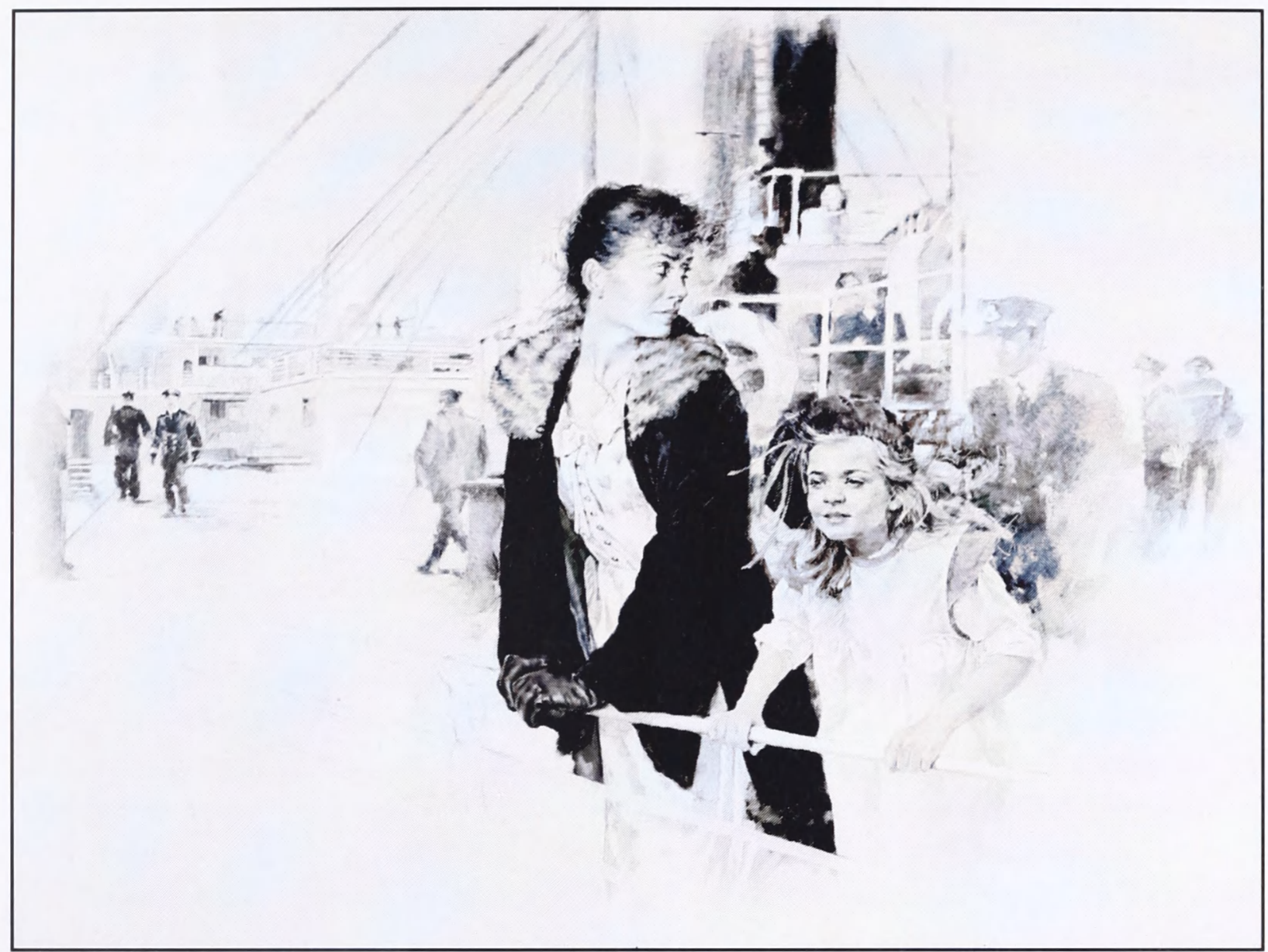

När man sammenligner illustrationen til sidste kapitel med billedet fra romanens start, kan man sagtens genkende hovedpersonen Anna. Men samtidig er der langt mellem den forvante overklassefrue i forste afsnit og kvinden på tegningen her.

den. Det er en søndag i februar.

\section{Hun skavede uroligt hen mod}

soldaterne. Måske var det bedst, hun vendte om oggik hjem!

Pludselig horte hun et hojtråb. "Til Nevskij!"

Hun vendte sig. Udstodte et forskrakket gisp...

En stor folkemangde var på vej ned ad Litejnij. De gik tat ved siden af hinanden $i$ hele gadens bredde. Rakke efter rakke så langt, ojet rakte.

"Ned i kna!" lod det bag hende. "Gevar ved skulder!"

Forst så det ud, som om der ikke var nogen af soldaterne, der ville efterkomme ordren. Men lidt efter lidt lagde de sig alligevel i skudstilling, sådan som de havde fäet besked på.

Mangden lod sig dog ikke anfagte af de truende gevarlob og fortsatte ufortrødent. Med et par korte stod i et signalhorn blev der givet tegn til at begynde skydningen.

Det gav et sat i Anna, og hun satte uvilkarligt handerne for orerne, sa hun slap for at hore skuddene.

Der skete imidlertid ingenting. $O g$ hun tog lettet handerne vak fra orerne igen. hundehoveder!"

"Fyr!" blev der så skreget. "Fyr, I

Nu bragede de forste skud. Og snart genlod gaden af hidsig gevarild. 
Menneskemangden trak sig redselslagen tilbage. Hoje, fortvivlede råb slog op mod husmurene. Angstfulde og afmagtige skrig. Brol af smerte og fortvivlelse...

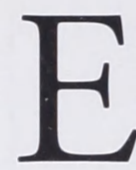

n så dramatisk scene er sjældent særlig lang i en føljetonroman. Det er denne her heller ikke - selvom den selvfølgelig er lidt længere end det uddrag, der er gengivet ovenfor. Den har sin funktion i handlingen, og den kunne bestemt ikke undværes. Men den slags uhyggelige begivenheder er næsten altid beskrevet forholdsvis kortfattet.

Helt anderledes er det med en scene senere i romanen. Her er Anna taget ud på Ismajlov familiens gods Lipovskoje sammen med Irina - en ung pige fra Narva kvarteret - og dennes lillesøster Natalja. Pigerne er begge mærket af sulten i Petrograd, og Anna håber, at et ophold på godset vil hjælpe dem med at komme til kræfter.

Denne scene får god plads. For Anna nyder tydeligvis samværet med de to piger, og læseren skal naturligvis have mulighed for helt og fuldt at tage del i denne stilfærdige glæde.

\section{"Se!" sagde Anna og pegede. "Det} derude er Den Finske Bugt."

Hun havde taget Natalja og Irina med op på en bakke, hvorfra man kunne se ud til havet. Langt borte fortonede det gräbla vand sig i horisonten - og oven over den la nogle lav thangende skyer, der godt kunne minde om en bjergrakke.

"Hvor er her flot...!" kom det henfort fra Irina.

"Og dér sejler et skib, "konstaterede Natalja ivrigt, mens hun stirrede ud mod en stor damper, hvor rogen valdede op af skorstenene.
De havde efterhänden varet ude $p a ̊$ godset $i$ et par uger. Og man kunne allerede se, at pigerne havde det bedre. De var ikke langere helt så radmagre - og der var ogsa ved at komme lidt farve i deres kinder...

Efter at have stået lidt og set ud over vandet, begyndte de at gå hjemad. De skulle jo helst vare tilbage for spisetid!

Da de var naet halvvejs ned ad bakken, markede Anna pludselig, at Natalja tog hende i hainden.

Hun blev helt varm indeni. Det var forste gang, pigen havde holdt $i$ haind, nair de var ude at gå. Og hun var helt uforberedt på, hvor rart det foltes.

For dem, som selv havde born, ville den slags vel bare vare noget ganske dagligdags. Noget, de slet ikke haftede sig ved, fordi de var så vant til det. Men for Anna var det en helt ny og overvaldende fornemmelse at marke den lille, spinkle haind, der klemte om hendes fingre...

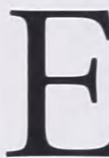
$\mathrm{n}$ sådan prioritering af handlingselementerne er ganske karakteristisk for en moderne føljetonroman. Det vigtigste er den almenmenneskelige historie. Den, som i dette tilfælde handler om Anna. Helt i front er hendes udvikling som person - tæt fulgt af kærlighedsfortællingen. I tredje række kommer så alt det, som danner baggrund for historien - her begivenhederne omkring den russiske revolution.

\section{I tykt og tyndt}

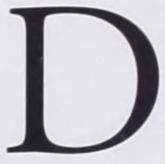

et er vistnok en udbredt opfat celse, at føljetonromaner beskriver erotik på en meget kysk måde. Et enkelt kys hist og her - men så ikke mere.

Sådan var det måske engang. Men tiderne har ændret sig, og det gælder også for føljetonerne. 


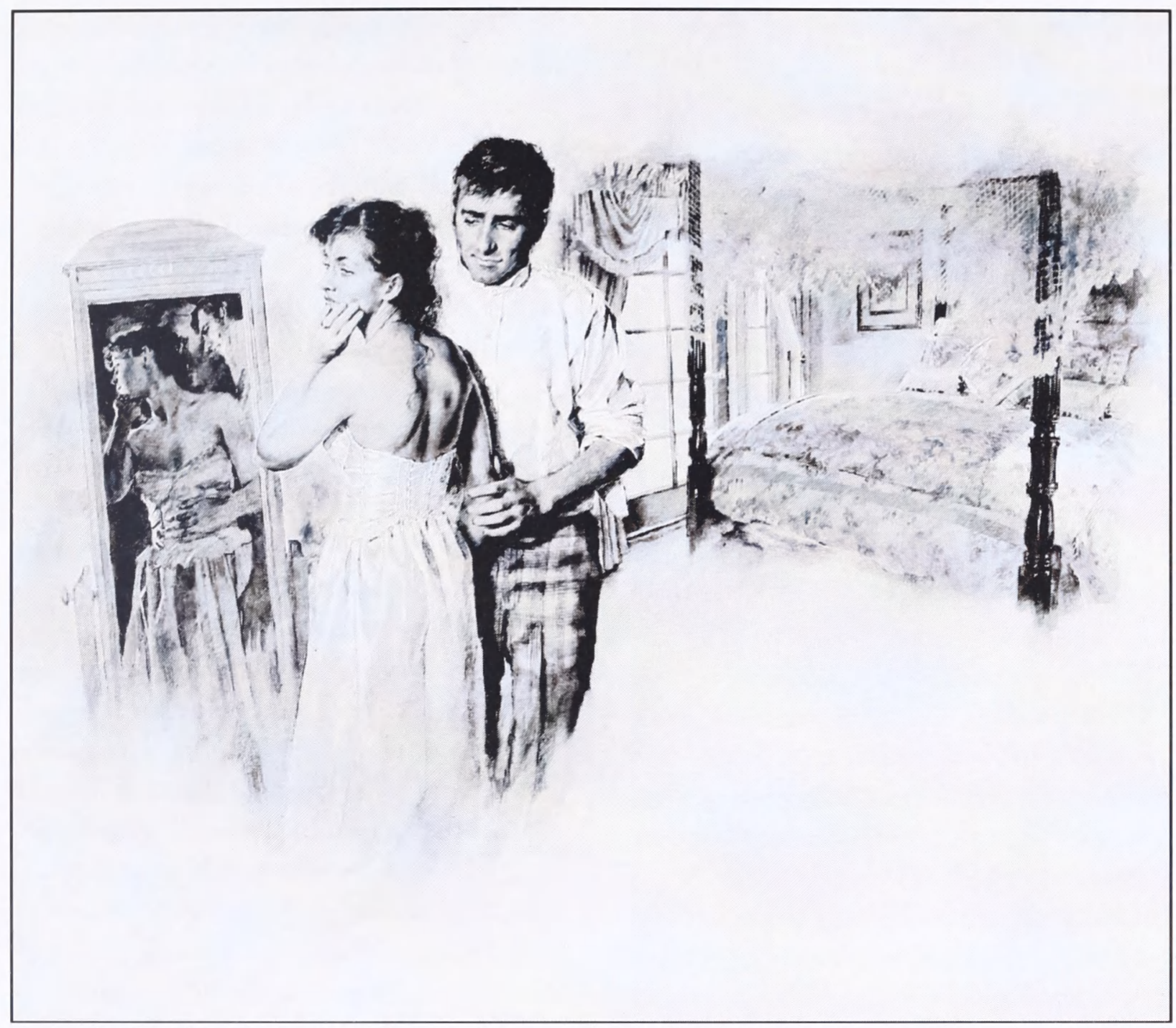

På Lesley Mackenzies råskitse til denne illustration var billedet i spejlet mere afslorende og pikant. Sådan er scenen også beskrevet $i$ romanteksten. Men man valgte alligevel at gore den fardige tegning lidt mere takkelig.

\section{Anna trykkede sig tat ind til}

Sergej...

Han tog hende om livet. Fortsatte nedad mod bagsiden af larrene. Sogte lidt opad igen. Klemte om hende.

Hun lagde hovedet tilbage.

Stonnede tungt.

Sergej gav sig til at kysse hende på halsen. Og Anna losnede de overste knapper $i$ sin kjole, så han også kunne kysse hende under halsudskaringen.

Han hev kjolen yderligere fra hinanden. Trak hendes bryster frem fra korsettet og pressede sine laber mod dem.
En varm kildren bredte sig fra spidsen afbrysterne. Små, glodende tråde, der lob helt ned i maven...

Anna gispede hojt. Og mens Sergej fortsatte med at kale med hende, knappede hun hele den overste del afkjolen op og trak den ud over armene.

Med ét kom hun til at kigge over mod det store spejl, der hang midt på den ene vag. Og hun kunne nasten ikke genkende sig selv! Var det virkelig hende, der stod dér med ildrode kinder og et fjernt og sloret udtryk i øjnene?

Hun flaede de sidste knapper $i$ 
kjolen op og lod den glide til jorden...

Jeg finder det ganske naturligt at have sådan en scene med i romanen. Vi er temmelig langt henne $\mathrm{i}$ handlingen, og læseren har hele vejen igennem fulgt Anna i tykt og tyndt. Så skal hun ikke snydes for dette højdepunkt i kærlighedshistorien.

\section{Cliff-hanger og happy ending}

\section{Anna markede noget härdt og} koldt, der blev presset mod hendes kind. Og da hun drejede ansigtet, kiggede hun direkte ind $i$ lobet på et gevar.

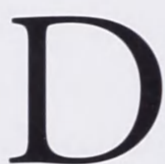

et er slutningen på syvende kapitel. Og det er jo en vaskeægte cliff-hanger. Der er en lang tradition for den slags kapitelslutninger i en føljeton - og som forfatter kan man næsten ikke kan dy sig for at bruge dem, når handlingen giver mulighed for det.

Alle kapitlerne ender dog ikke på den måde. Og det er nok også begrænset, hvor virkningsfuld sådan en cliff-hanger egentlig er. Læseren er jo ikke dum. I dette tilfælde ved hun f.eks. udmærket, at det ville stride afgørende mod genrens konventioner, hvis hovedpersonen fik skudt en kugle gennem hovedet. Og hun ville nok også spørge sig selv, hvad der i så fald skulle foregå i de to kapitler, der stadig mangler.

Det, som virkelig betyder noget $\mathrm{i}$ et afsnit, er, at historien tilføres noget nyt. At handlingen bevæger sig videre. Hvis der ikke i løbet af kapitlet er blevet føjet noget afgørende til det, vi har hørt i forvejen, vil læseren føle, at hun har spildt sin tid. Og det kan selv nok så megen dramatik i de sidste linjer ikke rette op på.
$\mathrm{D}$ er er en klar forventning om, at en føljetonroman har en form for happy ending. I Grevinde Ismajlova har læseren hele vejen igennem levet med i alle Annas problemer. Lidt med hende. Delt hendes forhåbninger. $\mathrm{Og}$ så ville det ikke være en tilfredsstillende forløsning af historien, hvis Anna endte med at tabe alting på gulvet.

Jeg skal åbent indrømme, at denne forventning om en happy ending af og til volder problemer. De store, klassiske fortællinger, hvor kærlighed spiller en afgørende rolle, ender jo stort set alle sammen ulykkeligt. Og hvis de ikke gjorde det, ville vi sikkert have glemt dem forlængst.

Nu er en føljeton ikke verdenslitteratur som f.eks. Romeo og Julie. Men ikke desto mindre sker det ofte, at handlingen trækker i retning af en tragisk afslutning; og så kan det være svært at fastholde kursen mod en positiv udgang. Det nytter nemlig ikke at forsøge at klistre en lykkelig slutning på en roman, hvis man i bund og grund synes, at den skulle ende anderledes. Det ville aldrig virke overbevisende; og læseren ville hurtigt kunne gennemskue, at der var noget galt.

Man må finde en slutning, man selv tror på - og som læseren samtidig vil opleve som den rigtige afslutning på fortællingen.

Selvom der helst skal være happy ending, er der dog ingen, der siger, at alt skal slutte i fryd og gammen. Der må gerne være både smil og tårer. Og det er der da også $\mathrm{i}$ denne roman...

\section{Cårerne gælder især Irina - en af de to piger fra fattigkvarteret. Anna har i et årstid boet sammen med hende} og hendes lillesøster, Natalja. Men da hun 
kommer til at lægge sig ud med det nye, bolsjevikiske styre, må de hovedkuls flygte fra Rusland - og under flugten bliver Irina dræbt.

Nu er Anna kommet til Paris med Natalja. Og for at tjene til dagen og vejen har hun lejet en beskeden teforretning i det russiske kvarter.

\section{Vinteren var kommet til Paris.}

Anna stod ved vinduet i forretningen og kiggede tankefuld ud på gaden. Snefnuggene dalede stille ned fra himlen. Lagde sig som et fint, hvidt toppe på fortovet.

Men uanset hvor kont, det så ud, var det nu ikke det samme, som når det var vinter hjemme i Petrograd! Der kunne snetappet blive så tykt, at man nasten sank $i$ tilknaene.

\section{Nogle gange langtes hun så} forfardeligt efter at se det hele igen. De pastelfarvede palaer ved Fontanka kanalen. Isen på vandet. Himlen, der var så lysende klar...

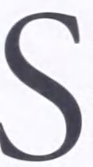
ådan begynder det sidste afsnit i det afsluttende kapitel; og det er ikke underligt, at Anna er noget melankolsk. Da der lidt efter kommer kunder i forretningen, fornemmer man dog, at hun egentlig trives ganske godt med sit arbejde. Og da kærlighedshistorien til allersidst får en uventet og positiv udgang, går det op for Anna, at hun nu har alle muligheder for at få det, hun ubevidst har søgt efter gennem hele romanen: Et rigtigt hjem. En meningsfuld tilværelse sammen med dem, hun holder af.

Og pludselig var det, som om langselen efter hjemlandet mistede sit tag $i$ hende. Det gjorde ikke langere noget, at husene i Paris var grå og ikke pastelfarvede. Eller at himlen ikke var så klar som i Petrograd. For $i$ dette ojeblik vidste hun, at det var her, hun horte til. I en teforretning i Rue Pierre le Grand...

$\mathrm{J}$ eg bliver af og til spurgt, hvorfor jeg skriver føljetonromaner. Det må da være frustrerende ikke at kunne skrive Røjagtig, hvad man har lyst til. At skulle bruge en ganske bestemt fortællestil.

Det er selvfølgelig et spørgsmål om temperament. Men jeg synes, at man inden for rammerne af denne genre sagtens kan fortælle en læseværdig historie. Hvis Grevinde Ismajlova havde været skrevet som bog, havde den naturligvis set meget anderledes ud. Blandt andet havde den været mindst tre gange så lang, som den er nu. Men jeg tror egentlig ikke, at den havde været bedre. Hvis jeg havde troet det, havde jeg ikke skrevet den som føljeton.

Man må heller ikke glemme, at de krav, som stilles til fortælleteknikken, udelukkende har ét formål: At få så mange som muligt af bladets læsere til at følge med i historien. Leve sig ind i den. Når læseren har brugt et kvarters tid på et romankapitel i Hjemmet, skal hun være så optaget af handlingen, at hun dårligt kan vente til næste uge med at få fortsættelsen. Og når hun efter et par måneder er færdig med det sidste afsnit, skal hun sidde tilbage med fornemmelsen af, at hun har tilbragt tiden i godt selskab.

Er det lykkedes, har føljetonforfatteren nået sit mål - og så kan man for alvor tale om en happy ending. 